Images in...

\title{
'Silent' but massive bilateral pulmonary embolic disease
}

\author{
R D Soysa, ${ }^{1}$ S W Dubrey, ${ }^{1}$ M T Dahdal, ${ }^{1}$ R Grocott-Mason²
}

${ }^{1}$ Department of Cardiology, Hillingdon Hospital, Uxbridge, UK

${ }^{2}$ Hillingdon Hospital, Uxbridge, UK

Correspondence to SW Dubrey, simon.dubrey@thh.nhs.uk

\section{DESCRIPTION}

An 80-year-old man presented to the facility, describing 6 months of increasing shortness of breath. Prior to admission, he had been bed bound for 5-7 days due to a chest infection. Observations revealed a pulse $79 / \mathrm{min}$, blood pressure $119 / 79 \mathrm{~mm} \mathrm{Hg}$ and a respiratory rate of $16 / \mathrm{min}$. Oxygen saturation levels were $95 \%$ on room air, and he was apyrexial. Aside from a 5 -cm raised, jugular-venous pressure and left-sided basal crepitations, physical examination was unremarkable. The full blood count, inflammatory makers and coagulation profile were normal. An ECG showed atrial fibrillation at 85 beats/min, and the chest $\mathrm{x}$-ray taken was normal.

An echocardiogram showed a large, mobile, lobulated, right-atrial mass (figure 1), an ejection fraction of $41-50 \%$, but no wall-motion abnormalities. The right ventricle was not dilated, but the pulmonary pressure was elevated at 46 $\mathrm{mm} \mathrm{Hg}+$ jugular venous pulse. Treatment dose of lowmolecular-weight heparin was initiated. The following day, a CT pulmonary angiogram showed large, bilateral, pulmonary emboli involving the bifurcation of both pulmonary trunks (figure 2). This scan showed no evidence of the right-atrial mass, which was also confirmed on repeat echo.

Despite this, the patient remained haemodynamically stable with unchanged oxygen saturations and an improvement in his breathing. The patient was loaded with warfarin. To date, no internal malignancy has been found to explain this thromboembolic event.

\section{Competing interests None.}

Patient consent Obtained.
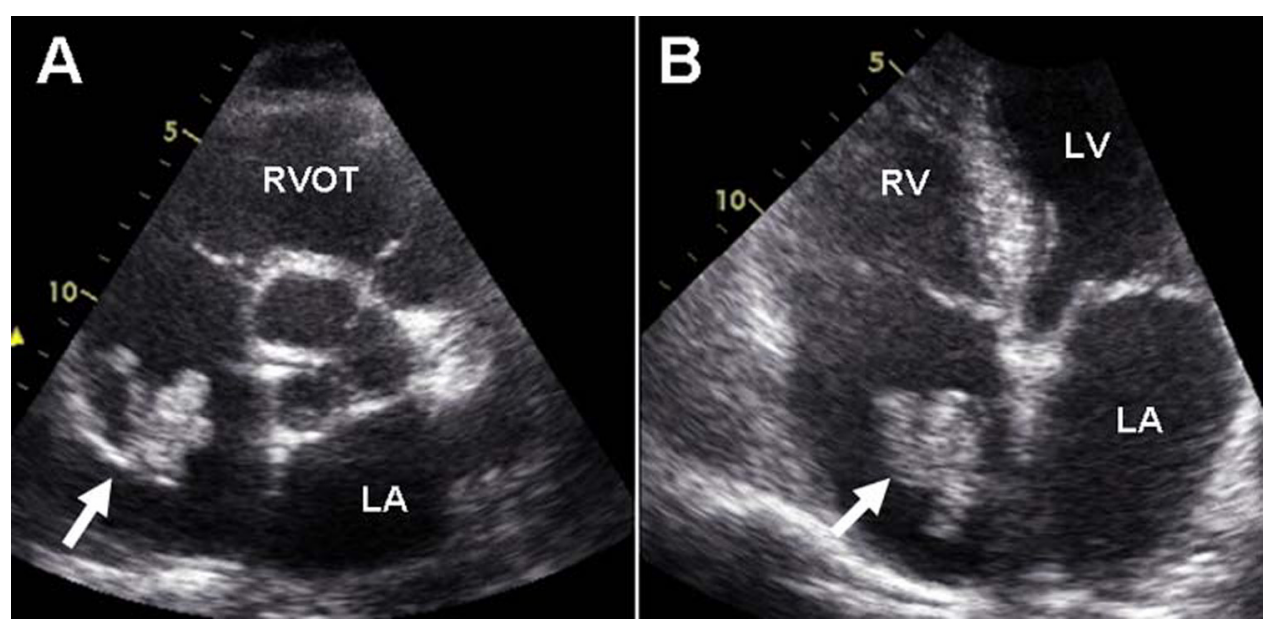

Figure 1 Echocardiographic parasternal short axis $(A)$ and apical 4-chamber (B) view, showing a large, lobulated mass (white arrow) within the right atrium. LA, left atrium; LV, left ventricle; RV, right ventricle; RVOT, right-ventricular outflow tract. 


\section{BMJ Case Reports}
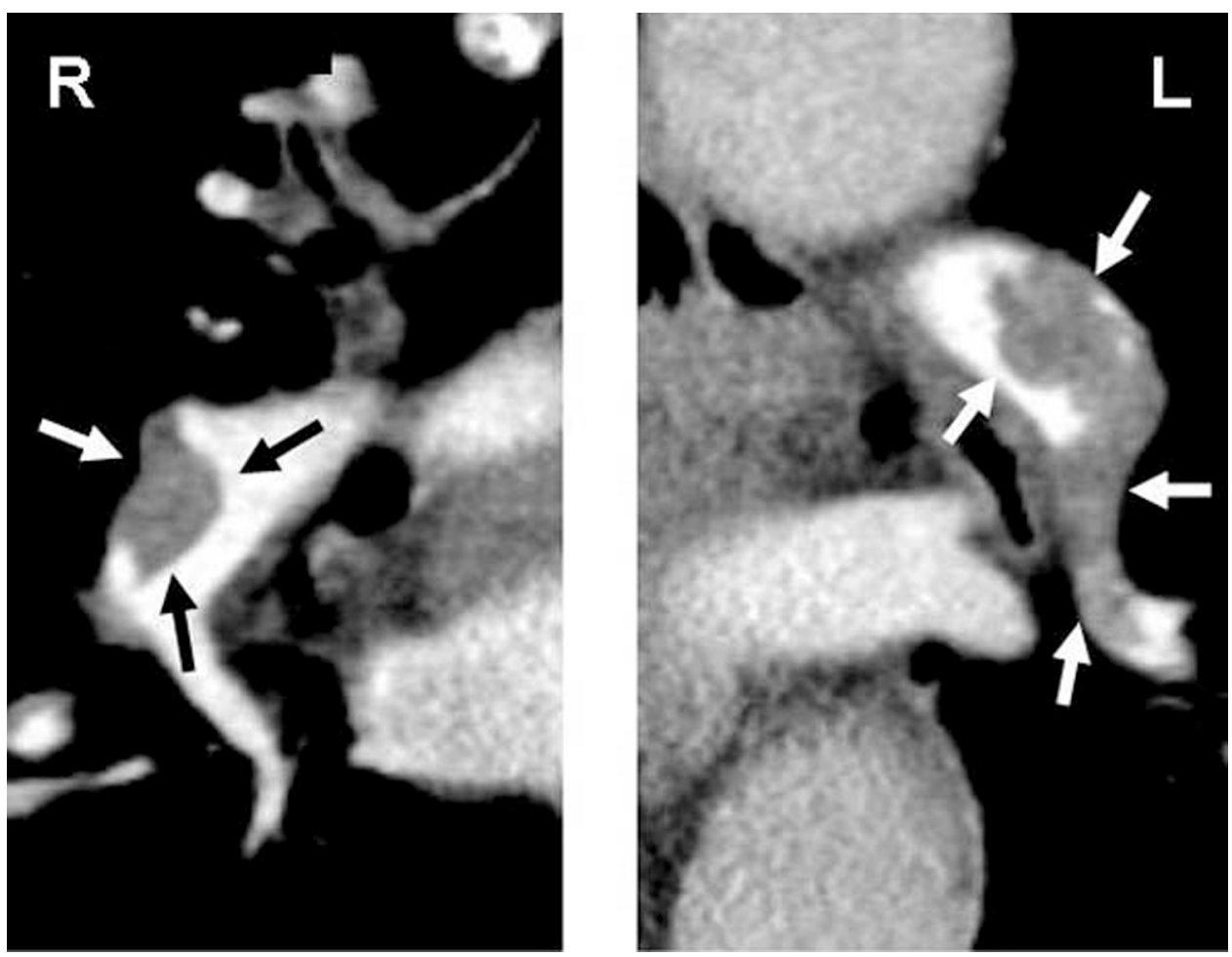

Figure 2 CT pulmonary angiogram showing thrombus (white and black arrows) as dark filling defects in the main right (R) and left (L) pulmonary arteries.

This pdf has been created automatically from the final edited text and images.

Copyright 2010 BMJ Publishing Group. All rights reserved. For permission to reuse any of this content visit http://group.bmj.com/group/rights-licensing/permissions.

BMJ Case Report Fellows may re-use this article for personal use and teaching without any further permission.

Please cite this article as follows (you will need to access the article online to obtain the date of publication).

Soysa RD, Dubrey SW, Dahdal MT, Grocott-Mason R. 'Silent' but massive bilateral pulmonary embolic disease. BMJ Case Reports 2010;10.1136/bcr.03.2010.2793, date of publication

Become a Fellow of BMJ Case Reports today and you can:

- Submit as many cases as you like

- Enjoy fast sympathetic peer review and rapid publication of accepted articles

- Access all the published articles

- Re-use any of the published material for personal use and teaching without further permission

For information on Institutional Fellowships contact consortiasales@bmjgroup.com

Visit casereports.bmj.com for more articles like this and to become a Fellow 